\title{
The Influence of Academic Achievements on the Quality of Employment for Undergraduates of Private Higher Education in China
}

\author{
Lian Cheng \\ Economic Management Department \\ WenHua College \\ Wuhan, China
}

\begin{abstract}
Based on the employment theory and the multiorder Logit model, this paper studies and analyzes the 2017 graduates of School of Economics and Management of the Mandarin University from the perspective of academic performance and personal characteristics. And it is found that the employment of students is closely associated with students' official weighted average scores, academic performance, professional grades and English grade. The results obtained in this paper show that for the improvment of the quality of employment, students should pay more attention to their academic achievements, at the same time, university should also strengthen the cultivation of students' learning abilities. Moreover, strict student management and teaching management should be carried out throughout the students' college life, and students' practical abilities also should be cultivated.
\end{abstract}

Keywords-Academic performance; Logit model; Private colleges; Employment quality

\section{INTRODUCTION}

At the end of the 20th century, China began to embark on the road to popularization of higher education. In China, private colleges and universities (including independent colleges) have developed rapidly under the founding of the new mechanism. In 2017, the total scale of China's higher education reached 36.99 million, accounting for one-fifth of the total scale of higher education in the world, and its scale ranked first in the world. The transformation of independent colleges has caused the graduates of private universities to face a more severe employment situation. The reforms in the popularization of colleges and universities, such as employment system reform, new contradictions, fairness, challenges, and opportunities, have become the focus of current attention. . At present, China mainly conducts research on employment statistics and predictions, employment status and causes, and employment strategies for graduates, and the numerous employment studies brought about by the popularization of education are basically aimed at publicly-run general and secondary vocational education. . However, the rapid development of private colleges and universities (including independent colleges) in the past decade has lacked corresponding attention and research.

\section{STATUS QUO AND SIGNIFICANCE OF RESEARCH ON} ACADEMIC ACHIEVEMENT AND EMPLOYMENT RELATIONSHIP

At the end of the 20th century, China began to embark on the road to popularization of higher education. In China, private colleges and universities (including independent colleges) have developed rapidly under the founding of the new mechanism. In 2016, the total scale of China's higher education reached 36.47 million people, and independent colleges were transformed. This made the graduates of private universities face a more severe employment situation, the institutional reform of employment, the new characteristics of contradictions, and the issues of equity in the popularization of colleges and universities. Problems such as challenges and opportunities have become the focus of current attention. At present, China mainly conducts research on employment statistics and predictions, employment status and causes, and employment strategies for graduates, and the numerous employment studies brought about by the popularization of education are basically aimed at publicly-run general and secondary vocational education. . However, the rapid development of private colleges and universities (including independent colleges) in the past decade has lacked corresponding attention and research.

Private universities mainly adopt the principle of "learning in and out strictly". When students enter the school, their average scores are often lower than those of public institutions. Although many college entrance examination candidates are given more opportunities, the overall quality of students is lower because of their low starting point. Compared with public universities, it is at a disadvantage. 


\section{A. The importance of university academic performance}

Today, with the rapid development of society, university students are very radical about their academic performance. They believe that university studies do not make much sense to themselves. This group of people lacks rational understanding and lacks understanding of the value of learning. However, in fact, there is a positive correlation between academic performance and employment quality. Students' academic achievement is an important manifestation of students' learning ability, self-discipline ability, and adaptability. This requires us to learn from the concepts and successful experiences of advanced universities at home and abroad. We must not only ignore academic achievement, but should strengthen the cultivation of students' learning ability and educate the ancestors. Kong Qiu's individualized education, which teaches students in accordance with their aptitude, runs through the students' college life and focuses on cultivating their practical abilities.

American academic achievement test method is worthy of China's reference. The U.S. college final exams account for only $35 \%$ of the total scores, and unlike China's pre-exam pressure, this not only eases the pressure on students' preparation for examinations, but also enables students to be more equitably assessed. In other words, the pros and cons of the final exam scores are not very important to the total scores, as long as the normal assignments are completed normally [1]. This achievement can effectively encourage college students to work hard in peacetime learning, but also reflects the importance of university academic performance [2].

\section{B. Effect of university academic performance on employment}

Since 2010, China has 7 million college graduates each year, but some of them cannot find jobs. The relevant parties have also used many measures to help employment, such as the development of employment protection channels for graduates, and the granting of entrepreneurial loans for college students. However, these channels cannot really eradicate the employment difficulties of university graduates. Then, how should college students, schools, parents, society and the government react? Tracing back to the source, the most controversial factor in the employment difficulties of college students is the university's academic performance and the influence of the major they have studied on employment. Academic performance is more relevant to employment. Now for many companies, the test scores of college students enrolled are as important as their graduation certificates, degree certificates and resumes. A considerable number of companies nowadays are not just looking at their diplomas, degree certificates, and resumes, but also their academic performance. More and more employers choose the factors of ideology, morality, professional achievement, professional counterparts, etc. as their criteria. Employers believe that students with excellent academic performance are diligent, learnable, have strong learning ability, have full confidence in employment, and can become qualified employees in the company.

\section{Importance of personality cultivation for college students}

Dr. Duckworth, an associate professor at the University of Pennsylvania, believes that self-control over IQ can be used to judge student's future academic performance. However, it is not only traditional perseverance. Can a college student maintain continuous passion and endurance for long-term goals and can not be invested in it? Doing what you like is fundamental, this is a personality trait that includes selfmotivation, restraint, and adjustment. Actual operation ability refers to a person's ability to convert intangibles into visible ones and must be possessed by workers [3]. Practical work practice is different from textbook theory knowledge, especially in the front line of teaching, scientific research and production. The strength and weakness of the actual operating ability of graduates will directly affect their employment. Because of traditional Chinese exam-oriented education concepts, private school graduates (including independent colleges) only pay attention to studying theoretical knowledge on books during school, and the employment service system of private schools (including independent colleges) is not perfect, resulting in the theory of most university graduates. Strong, lack of practice, can not combine theory and practice. Many contemporary college students are bound by exam-oriented education and rarely participate in various social practice activities. Therefore, this situation needs improvement.

\section{Misunderstandings of Academic Performance of Private College Students}

Nowadays, college students do not have the hearts and minds of the predecessors who really studied hard at the university because of their rare learning opportunities. They dismissed the attitude of learning. Some colleges even just took time to spend their days. Many people were in the exam. Days of raids, and even some still simply "naked exams," not to mention genuine concern for academic studies. The time for setting up private colleges and universities in China is short, and a strong learning atmosphere has not yet formed. Private college students do not fully understand the value of learning. Many college students think that studying at a university is for a paper diploma, and it will be helpful for university students to learn their work. There is doubt in this area, and there is a lack of correct and rational thinking about learning. The impact of failure in the study before the college entrance examination made the students of private colleges and universities to reject learning and hate learning. Private colleges and universities in China are charged according to the cost of running a school. Tuition fees are relatively high. Most students who can come to study are in good condition. A large number of students think that good performance is not as good as "hard work." Many people think that learning is not as good as their family, as long as their family is good. The problems of employment and life can be solved so as to form a low learning atmosphere, resulting in no attention to academic achievement. 


\section{ECONOMETRIC ANALYSIS AND CONCLUSION}

This article collects relevant data of 2017 graduates of the School of Economics and Management of the Mandarin University (formerly Huazhong University of Science and Technology Wenhua College) and in order to establish a multivariate logit regression analysis model, this paper processes the collected data as follows:

The personal characteristics and academic performance of college students are discrete variables with sorting characteristics: the impact on students' employment, including gender, height, type of residence, whether or not there are party members, whether they are poor, whether they are student cadres, personal characteristics, and weighted average scores. , professional course performance, whether to pass the computer grade two and English four grade academic performance. The distribution of its choice is more in line with the assumption of the Logit model. Therefore, this paper chooses the multivariate sorting Logit model to analyze the impact of academic studies on the employment of college students. Because the samples were taken from different professional graduates of the 2017 Graduate School of Economics and Management of the Mandarin University (formerly Huazhong University of Science and Technology), the professional course performance data were comparable after being standardized. To classify the employment situation of undergraduate graduates in 2017: First no work Second, private small enterprises Third, private large enterprises / state-owned General Fourth, state-owned largescale, public institutions, civil servants, multinational companies.

\section{A. Sample selection and measurement model}

According to the analysis of the existing literature, the factors that affect student employment mainly include personal characteristics and academic performance. Academic achievements include the weighted average scores, professional grades, whether they pass the computer second grade and English four grades, personal characteristics include gender, height, type of account, whether the party members, whether it is poverty, whether or not as student cadres. Model setting and variable meaning: The explained variable is employment. The explanatory variable includes gender, height, type of residence, whether or not the party member, whether it is poverty, whether it is student cadre, weighted average score, professional grades, whether it passes the second level of computer, and English four. Grade achievement.

- Overall performance characteristics in academic performance. The four-year weighted average score of college students can better reflect students' learning ability and inquiry ability. This article will use it as an indicator to measure the quality of employment.

- Professional literacy characteristics in academic performance. College students' professional grades can reflect professional skills and concentration levels to a large extent. This article uses it as an indicator of the quality of employment.

- English characteristics in academic performance. The English four grades provide the choice environment and scope for college students' career and education choice decision. This paper sets it as a variable to characterize the quality of employment.

- Computer capabilities in academic performance. Computer second level is a good indicator that students master the office automation ability. Students have a certain level of influence on finding a job through the second grade. Therefore, this article will use it as an indicator to measure the quality of employment.

- Personal characteristics. Differences in educational opportunities and the labor market's gender, height, student cadre experience, etc. are the controlling factors often considered in previous studies. Therefore, this article will include gender height, type of residence, whether or not party members, whether they are poor, and whether they serve as student leaders. As a control variable. 


\section{B. Analysis of Models by Using Multivariate Logit Regression}

Based on the principal component load matrix, series 1 can represent academic performance other than computers, and series2 represents computer-level competence. The two sequences were used to sort multiple logit regressions with the gender, height, type of residence, whether party members, poverty, and whether they were serving as student cadres 6 control variables as explanatory variables and job types as explanatory variables. The results are as follows:

TABLE I MULTIVARIATE LOGIT MODEL REGRESSION 1

\begin{tabular}{|c|c|c|c|c|}
\hline Variables & Coefficients & Standard Deviation & Z Values & Probability \\
\hline series1 & 0.280398 & 0.09695 & 2.892184 & 0.0038 \\
\hline series2 & -0.03607 & 0.080195 & -0.44982 & 0.6528 \\
\hline gender & -0.14637 & 0.283291 & -0.51668 & 0.6054 \\
\hline cadre & 0.568214 & 0.177247 & 3.205765 & 0.0013 \\
\hline party & -0.32897 & 0.237751 & -1.38368 & 0.1665 \\
\hline poor & 0.129478 & 0.193298 & 0.669835 & 0.503 \\
\hline urban & -0.2083 & 0.173108 & -1.20328 & 0.2289 \\
\hline height & 0.017883 & 0.016317 & 1.095943 & 0.2731 \\
\hline \multicolumn{4}{|c|}{ Limit Points } \\
\hline LIMIT_2:C(11) & 0.540611 & 2.627209 & 0.205774 & 0.837 \\
\hline LIMIT_3:C(12) & 3.697795 & 2.632241 & 1.404809 & 0.1601 \\
\hline LIMIT_4:C(13) & 6.035042 & 2.639998 & 2.286003 & 0.0223 \\
\hline LR statistic & 26.37759 \\
\hline Prob(LR statistic)
\end{tabular}

The multivariate logit model regression results show that the $\mathrm{P}$ values of each explanatory variable are only series 1 and cadre, and the two variables are less than 0.05 . That is to say, only the academic performance (weighted average scores, professional grades, English grade 4 scores) and whether they have served as cadres other than computers have a significant effect on the quality of employment. From the above, we adopt the backward culling method to eliminate independent variables that do not significantly affect the employment category [4].

TABLE II MULTIVARIATE LOGIT MODEL REGRESSION 2

\begin{tabular}{|c|c|c|c|c|}
\hline Variables & Coefficients & Standard Deviation & Z Values & Probability \\
\hline series1 & 0.243196 & 0.080203 & 3.032269 & 0.0024 \\
\hline cadre & 0.509654 & 0.166798 & 3.055522 & 0.0022 \\
\hline \multicolumn{5}{|c|}{ Limit Points } \\
\hline LIMIT_2:C(3) & -2.22183 & 0.146253 & -15.1917 & 0.0000 \\
\hline LIMIT_3:C(4) & 0.913134 & 0.103413 & 8.829966 & 0.0000 \\
\hline LIMIT_4:C(5) & 3.242432 & 0.199299 & 16.26922 & 0.0000 \\
\hline LR statistic & \multicolumn{5}{|c|}{0.0000030} \\
\hline Prob(LR statistic) & \multicolumn{5}{|c|}{0.838} \\
\hline
\end{tabular}

The job=0.243196 series $1+0.509654$ cadre coefficient is positive, indicating that academic performance (weighted average scores, professional grades, English grade 4 scores) and serving officers have a positive effect on the quality of employment. That is, the higher the academic achievement (weighted average score, professional course score, and English grade 4 score) than the computer, the higher the possibility of finding a more stable and better job; and based on the principal component load matrix of the principal component analysis, the academic performance (Weighted average score, professional course scores, English grade 4 scores) The effect of the graduates on finding a more stable and better job is in the order of weighted average score> professional course score> English grade four. Computer scores are statistically insignificant for graduates to find more stable and better jobs. Serving as a student cadre has a positive influence on finding a more stable and better job. According to the regression equation, those who have experience as student cadres are on average 0.51 more grades than those who do not have student cadre experience. 


\section{Conclusion}

First, the external factors such as gender, height, type of residence, whether the party member and the poor student in the student's employment process do not significantly determine the quality of the student's employment, academic performance (weighted average score, professional course performance, English level 4 The two variables, grades, and whether they served as cadres have a significant effect on the quality of employment.

Second, academic performance (weighted average scores, professional grades, English grade 4 scores) and serving as cadres have a positive effect on the quality of employment. That is, the higher the academic achievement, the higher the possibility of finding a more stable and better job; the effect of academic achievement on the graduates finding a more stable and better job is the order of the weighted average score> professional course achievement> English four grades. The weighted average score in academic achievement can be understood as the ability of the students' overall quality to have the most significant influence on students' finding a better job. However, those who have experience as student cadres generally have higher average grades than those who do not have student cadre experience.

\section{IMPROVING EMPLOYMENT RECOMMENDATIONS FOR UNDERGRADUATE GRADUATES FROM PRIVATE HIGHER EDUCATION IN CHINA}

\section{A. To develop a full-person education model to provide more practical platforms for student development}

The growth of students needs to lead the way. Schools should provide a broad platform for students' practice. Classes, student organizations, volunteer service organizations, etc. are the stage for students. Students' cadres have the sense of ownership, and they can grow their talents in practice and cultivate their responsibilities. The team of student cadres who are strong in communication, able to write and plan well, will drive all students. The development needs of enterprises and schools have a deep connection, to promote the implementation of school and business cooperation. Therefore, in addition to school practice, the school should also provide students with more opportunities for off-campus practice, so that students can learn more about social changes and requirements for employees in the student era. The private colleges and universities in China must carry out the mode of educating all the people and provide more practical platforms for the growth of students.

\section{B. Cultivate graduates with correct ideas and comprehensive qualities}

The key to student job hunting is mentality. Students graduating from private schools (including independent colleges) should not compare their shortcomings with the advantages of others when seeking a job, but should be flexible and flexible. Should adjust their own job intension with their own strengths and strengths, focusing on the future direction of career development and career nature. It is necessary to guide the graduates to establish confidence, reasonably position their expectations, and employ them before choosing jobs.

Basic occupational skills are skills that each candidate must possess before he/she is employed. It is different from professional skills, which is usually referred to as a skill, because it has basic and universal guidance. Take the humanities graduate job seekers as an example. Their basic professional skills include social etiquette, office software operations, and document writing. These basic skills are essential for graduates before they enter the job. With the post90 college graduates officially entering the workplace, the role of the "double-edged sword" has gradually emerged. On the one hand, they are the new force of the society, injecting fresh blood into the workplace, adding vitality and vitality. On the other hand, the insufficiency in their own ability and will quality has also become a headache for employers. It is necessary to guide graduates to improve their ability and quality, to develop their will and moral character, to master basic professional skills, and to adapt to market demands.

\section{Pay close attention to the quality of teaching and pay attention to the cultivation of students' comprehensive results}

The quality of teaching should be the top priority of school development. Its strategic position should be the most prominent and should occupy the most important place in the student's university training. The quality of teaching is the lifeline of the school. The most fundamental and direct standard for measuring the quality of a school is the quality of teaching. We should clearly see that the teaching quality of a considerable part of the private colleges and universities, a considerable part of the private colleges and universities is still not ideal. Teachers are the direct impetus to the improvement of teaching quality. Schools should try their best to cultivate a team of teachers who love and respect jobs and pay attention to teaching quality.

In order to improve the quality of employment, not only can academic performance not be ignored, but strict teaching management must be carried out throughout the student's college life. Schools should change their teaching concepts, take students as the center, use various methods so that students can set clear learning goals, and gradually improve their ability to work hard, learn and listen. The evaluation of the academic performance of institutions of higher learning should change their concepts, adopt positive and effective measures, properly play the examination function, and strive to solve the backward system that determines the success or failure of students with test scores. Passing to college students should understand how to lower their own mentality and go with the attitude of common laborers. The concept of a new era to participate in 
the employment competition completely eliminates the problems brought about by the old evaluation system.

\section{REFERENCES}

[1] Fred Thompson, William Zumeta. Effects of key state policies on private colleges and universities: sustaining private-sector capacity in the face of the higher education access challenge, Economics of Education Review, 2001, Vol.20 (6), pp.517-531.

[2] Mortimer, Employment problems for graduates in the United States, Higher Education in Europe, 06 Jul 2006.

[3] The Public Criticism and Standardization of Obama's Education Reform [D]. Plateau. East China Normal University 2017.

[4] Research on Problem Solving Capability of International Student Assessment Project (PISA) Based on Log Data [D]. Lu Hao. East China Normal University 2017. 